\title{
Pengukuran Tingkat Kematangan Ketersediaan Layanan Akademik pada Sistem Informasi Akademik Menggunakan COBIT 4.1
}

\author{
Maturity Level Measurement of Academic Services Availability on \\ Academic Information Systems Using COBIT 4.1
}

\author{
Arga Fiananta*1, Kusrini ${ }^{2}$, Asro Nasiri ${ }^{3}$ \\ ${ }^{1,2,3}$ Program Pasca Sarjana Universitas Amikom Yogyakarta \\ E-mail: ${ }^{* 1}$ argafiananta@gmail.com, ${ }^{2}$ kusrini@amikom.ac.id, ${ }^{3}$ asro@amikom.ac.id
}

\begin{abstract}
Abstrak
Penelitian ini membahas tentang pengukuran tingkat kematangan ketersediaan layanan akademik pada Sistem Informasi Akademik di Institut Seni Indonesia Yogyakarta dengan menggunakan framework COBIT 4.1. Penelitian ini bertujuan untuk mengetahui tingkat kematangan ketersediaan layanan akademik pada Sistem Informasi Akademik di Institut Seni Indonesia Yogyakarta. Fokus penelitian ini terdapat pada beberapa domain pada COBIT 4.1, yaitu DS3, DS4, DS8, DS13. Hasil pengukuran tingkat kematangan ketersediaan layanan akademik pada Sistem Informasi Akademik di Institut Seni Indonesia Yogyakarta berdasarkan pada framework COBIT 4.1 yaitu sebesar 3.07 atau dengan tingkat kematangan di level 3 (Defined). Ini membuktikan tingkat ketersediaan layanan akademik pada Sistem Informasi Akademik di Institut Seni Indonesia Yogyakarta berada di tahap dimana pihak manajemen telah berhasil menciptakan dan mengkomunikasikan standar baku pengelolaan proses-proses TI yang terkait walaupun belum terintegrasi sepenuhnya. Sedangkan tingkat kematangan yang diharapkan berada pada tingkat 4 (Managed and Measurable). Untuk mencapai pada tingkat kematangan yang diharapkan, maka manajemen Institut Seni Indonesia Yogyakarta perlu menerapkan rekomendasi perbaikan yang telah diberikan pada masing-masing atribut kematangan.
\end{abstract}

Kata Kunci-COBIT 4.1, Sistem Informasi Akademik, Tingkat Kematangan, Institut Seni Indonesia Yogyakarta

\begin{abstract}
This study discusses the measurement of the level of maturity of the availability of academic services in the Academic Information System at the Indonesian Institute of The Arts of Yogyakarta using the COBIT 4.1 framework. This study aims to determine the level of maturity of the quality of academic services in the Academic Information System at the Indonesian Institute of The Arts of Yogyakarta. The focus of this research is on several domains in COBIT 4.1, namely DS3, DS4, DS8, DS13. The results of measuring the level of maturity of the availability of academic services in the Academic Information System at the Indonesian Institute of Arts in Yogyakarta are based on the COBIT 4.1 framework which is 3.07 or with a level of maturity at level 3 (Defined). This proves the level of availability of academic services in the Academic Information System at the Indonesian Institute of The Arts of Yogyakarta at the stage where management has succeeded in creating and communicating the standard management standards for related IT processes, although not yet fully integrated. While the expected level of maturity is at level 4 (Managed and Measurable). To reach the expected level of maturity, the management of the Indonesian Institute of The Arts of Yogyakarta needs to implement the recommendations for improvement given to each of the attributes of maturity.
\end{abstract}

Keywords - COBIT 4.1, Academic Information System, Maturity Level, Indonesian Institute of The Arts of Yogyakarta 


\section{Pendahuluan}

Pelayanan dalam bidang akademik adalah salah satu aktivitas utama perguruan tinggi yang berfungsi sebagai penyelenggara pendidikan. Dalam melaksanakan pelayanan ini diperlukan Teknologi Informasi yang akan memberikan kemudahan, kecepatan serta kenyamanan sehingga dapat meningkatkan kualitas layanan kepada pengguna. Untuk sebagian besar institusi, informasi dan teknologi yang mendukung kegiatan perguruan tinggi merupakan asset yang berharga. Perguruan tinggi yang sukses biasanya memahami keuntungan dan kegunaan dari teknologi informasi untuk mendukung kinerja perguruan tinggi. Perguruan tinggi juga memahami dan mengelola risiko-risiko yang berhubungan, seperti peningkatan pemenuhan pengaturan dengan banyaknya proses bisnis yang secara kritikal bergantung terhadap teknologi informasi [1].

Institut Seni Indonesia Yogyakarta adalah sebuah lembaga pendidikan tinggi seni berstatus perguruan tinggi negeri dalam lingkungan Kementerian Riset dan Pendidikan Tinggi yang dibentuk atas dasar Keputusan Presiden Republik Indonesia No. 39/1984 tanggal 30 Mei 1984 dan diresmikan oleh Menteri Pendidikan dan Kebudayaan Prof. Dr. Nugroho Notosusanto pada tanggal 23 Juli 1984. Institut Seni Indonesia Yogyakarta dibentuk berdasarkan fusi atas tiga pendidikan tinggi seni yaitu Sekolah Tinggi Seni Rupa Indonesia "ASRI", Akademi Musik Indonesia "AMI", dan Akademi Seni Tari Indonesia "ASTI" (http://isi.ac.id/profile/sejarah/).

Institut Seni Indonesia Yogyakarta yang terletak di Jalan Parangtritis Km. 5.5 Panggungharjo, Sewon, Bantul memiliki 4 fakultas yaitu Fakultas Seni Pertunjukan, Fakultas Seni Rupa, Fakultas Seni Media Rekam, dan Fakultas Pascasarjana yang memiliki dan memiliki 22 Program Studi yang terbagi ke dalam 4 fakultas tersebut. Dengan banyaknya Program Studi dan bertambahnya jumlah mahasiswa, Institut Seni Indonesia Yogyakarta harus selalu meningkatkan kualitas pelayanan di bidang akademik, terutama dalam ketersediaan Sistem Informasi Akademik yang digunakan. Hal tersebut agar proses pelayanan akademik dapat berjalan secara optimal.

Secara garis besar permasalahan yang terjadi di Institut Seni Indonesia Yogyakarta dapat dikategorikan menjadi 2 kategori, yaitu masalah strategis dan masalah teknis. Secara strategis renstra Institut Seni Indonesia Yogyakarta belum merencanakan secara spesifik untuk pengembangan sistem informasi, serta proses identifikasi masalah yang akan dihadapi serta cara penanggulangannya pun belum direncanakan secara spesifik. Secara teknis, permasalahan yang dihadapi diantaranya kerusakan jaringan (baik dikarenakan bencana alam maupun human error), server yang sering down pada jam produktif, ketidaksiapan SDM dalam mengimplementasikan aplikasi yang sudah disiapkan dari DIKTI, permasalahan yang terjadi karena pihak ketiga, serta kurangnya SDM yang cakap dan terampil dalam mengoperasikan Sistem Informasi Akademik yang ada di Institut Seni Indonesia Yogyakarta.

Berdasarkan pemaparan permasalahan pada paragraf sebelumnya, maka perlu dilaksanakan pengukuran tingkat kematangan ketersediaan sistem informasi akademik dalam Customer Perspective dengan Bussiness Goals (Improve Customer orientation and service) serta IT Goals (Make sure that IT services are available as required) sesuai dengan standar yang ada pada Framework COBIT 4.1. Pengukuran ini dilakukan guna mengetahui tingkat kematangan (maturity level) dari penyediaan layanan Sistem Informasi Akademik di Institut Seni Indonesia Yogyakarta untuk kemudian diidentifikasi permasalahan yang terjadi untuk menentukan strategi peningkatan layanan Sistem Informasi Akademik di Institut Seni Indonesia Yogyakarta.

Aktivitas audit dilakukan demi memberikan gambaran proses TI yang berlangsung di perusahaan masa kini kemudian mengamati, menganalisa dan menyesuaikan gambaran tersebut dengan ketetapan, standar, regulasi dan hukum yang berlaku [2].

Control Objectives for Information and Related Technology (COBIT) adalah kerangka kerja dan perangkat pendukung yang memungkinkan manajer untuk menjembatani kesenjangan sehubungan dengan persyaratan kontrol, masalah teknis dan risiko bisnis, dan 
mengkomunikasikan tingkat kontrol itu kepada pemangku kepentingan. COBIT memungkinkan pengembangan kebijakan yang jelas dan praktik yang baik untuk kontrol TI di seluruh perusahaan. COBIT terus diperbarui dan diselaraskan dengan standar dan panduan lainnya. Oleh karena itu, COBIT telah menjadi integrator untuk praktik TI yang baik dan kerangka kerja untuk tata kelola TI yang membantu dalam memahami dan mengelola risiko dan manfaat yang terkait dengan TI. Struktur proses COBIT dan pendekatan tingkat tinggi, berorientasi bisnis memberikan pandangan TI menyeluruh dan keputusan yang harus diambil tentang TI [3].

Manfaat penerapan COBIT sebagai kerangka kerja tata kelola TI meliputi [3] :

1. Penyelarasan yang baik, berdasarkan fokus bisnis.

2. Pandangan, dapat dimengerti oleh manajemen, tentang apa yang dapatdilakukan oleh TI.

3. Kepemilikan dan tanggung jawab yang jelas, berdasarkan pada orientasi proses.

4. Penerimaan umum dengan pihak ketiga dan regulator.

5. Pemahaman bersama di antara semua pemangku kepentingan.

6. Pemenuhan persyaratan COSO untuk lingkungan pengendalian TI.

Bagian ini memberikan gambaran tentang model tingkat kematangan yang menunjukan status lingkungan pengendalian internal dan pembentukan pengendalian internal dalam suatu perusahaan. Ini menunjukan bagaimana manajemen pengendalian internal, kesadaran akan kebutuhan untuk membangun control internal yang lebih baik, biasanya dikembangkan dari tingkat $a d$ hoc ke tingkat yang dioptimalkan. Model ini menyediakan panduan tingkat tinggi untuk membantu pengguna COBIT memahami apa yang diperlukan untuk kontrol internal yang efektif di IT dan untuk memposisikan perusahaan mereka pada skala tingkat kematangan [3].

Selain itu, urutan tingkat kematangan tata kelola TI secara keseluruhan ditunjukkan pada gambar 1. Melalui gambar tersebut, dapat dilihat grafik tingkat kematangan yang ada pada COBIT.

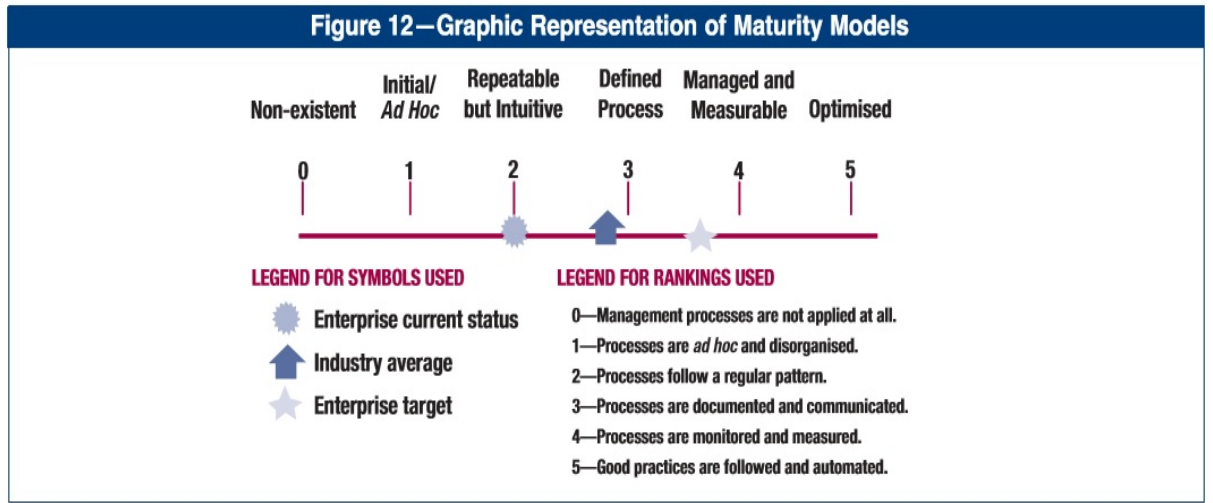

Gambar 1. Graphic Representation of Maturity Models

Berdasarkan gambar 1, skala maturity dibagi memiliki 6 level yaitu [3]:

- Level 0 Non-Existent - Pengelolaan teknologi informasi / sistem informasi masih dalam tahap paling awal, masih pemula. Setiap proses belum terdefinisi dengan baik.

- Level 1 Initial - Organisasi telah menyadari adanya persoalan yang perlu untuk ditangani, tetapi belum ada standar proses yang harus dilakukan. Penanganan persoalan dilakukan berdasarkan kasus-kasus yang muncul.

- Level 2 Repeatable but Instuitive - Proses telah dikembangkan pada tahap ini sehingga telah dilakukan prosedur yang sejenis untuk kegiatan yang sama.

- Level 3 Defined Process - Prosedur telah standarisasi, didokumentasikan, dan dikomunikasikan melalui pelatihan.

- Level 4 Managed and Measurable - Pada tahap ini manajemen mengawasi dan mengukur hal-hal yang telah dipenuhi dengan prosedur, serta mengambil tindakan ketika proses tidak berjalan dengan efektif. 
- Level 5 Optimised - Proses yang ada telah disesuaikan dengan best practice, berdasarkan hasil pengembangan secara terus-menerus dengan organisasi lain.

RACi Matrix merupakan bagian dari RAM (Responsibility Assignment Matrix), adalah tool yang digunakan untuk menampilkan penugasan tiap-tiap anggota project untuk masingmasing aktivitas. Penugasan untuk tiap anggota bisa berbeda-beda tergantung skill dan tanggung jawab yang dibebankan. Perbedaan tersebut direpresentasikan dengan huruf R-A-C-I. Berikut penjelasan peran dan fungsi di dalam RACI memiliki definisi yang lebih spesifik yaitu [3]:

- R-Responsible. Pihak-pihak yang bertanggungjawab untuk mengerjakan aktifitas yang dimaksud. Dalam setiap aktifitas, bisa terdapat lebih dari 1 orang.

- A-Accountable. Pihak yang memiliki otoritas dan akuntabilitas untuk aktifitas yang dimaksud. Berarti pihak ini memiliki tanggung jawab utama untuk memastikan keberhasilan pengerjaan aktifitas tersebut. Dalam setiap aktifitas, hanya boleh ada 1 orang.

- C-Consulted. Pihak-pihak yang akan dihubungi untuk konsultasi dan dimintakan nasihat mengenai aktifitas yang dimaksud. Dalam setiap aktifitas, bisa terdapat lebih dari 1 orang.

- I-Informed. Pihak-pihak yang akan di informasikan mengenai perkembangan pengerjaan aktifitas yang dimaksud. Dalam setiap aktifitas, bisa terdapat lebih dari 1 orang.

\section{Metode Penelitian}

Jenis penelitian yang penulis gunakan dalam penelitian ini adalah dengan menggunakan jenis penelitian Studi Kasus, yakni dengan mengamati fenomena yang terjadi pada objek penelitian yaitu pada Sistem Informasi Akademik di Institut Seni Indonesia Yogyakarta. Sedangkan penelitian yang akan penulis lakukan sifatnya adalah deskriptif yang bertujuan untuk membuat deskripsi secara sistematis, faktual dan akurat mengenai fakta suatu keadaan yang sedang berjalan pada Sistem Informasi Akademik di Institut Seni Indonesia Yogyakarta . Kemudian melakukan analisa menggunakan pendekatan penelitian kualitatif. Penelitian yang dilakukan menggunakan prosedur standar yang terdapat pada Framework COBIT 4.1 sebagai alat analisa dengan menggunakan tabel daftar responden, rumus.

\subsection{Metode Pengumpulan Data}

Metode pengumpulan data yang dilakukan penulis dalam penelitian ini adalah dengan melakukan observasi terkait permasalahan yang sedang terjadi pada Sistem Informasi Akademik di Institut Seni Indonesia Yogyakarta. Pengumpulan data dilakukan dengan kuisioner dan wawancara. Identifikasi responden berdasarkan RACI (Responsible, Accountable, Consulted, and Informed) Chart pada Framework COBIT 4.1 yang disesuaikan dengan struktur organisasi di Institut Seni Indonesia Yogyakarta. Daftar pertanyaan dan pernyataan pada tabel kuisioner mengacu pada Framework COBIT 4.1 berdasarkan variable-variabel yang terdapat pada Customer Perspective dengan Bussiness Goals (Improve Customer orientation and service) serta IT Goals (Make sure that IT services are available as required) sesuai dengan standar yang ada pada Framework COBIT 4.1.

\subsection{Alur Penelitian}

Untuk melakukan penelitian dengan metode deskriptif, penelitian dilakukan dengan beberapa tahapan penelitian. Gambar 2 akan menjelaskan alur penelitian yang akan dilakukan. 


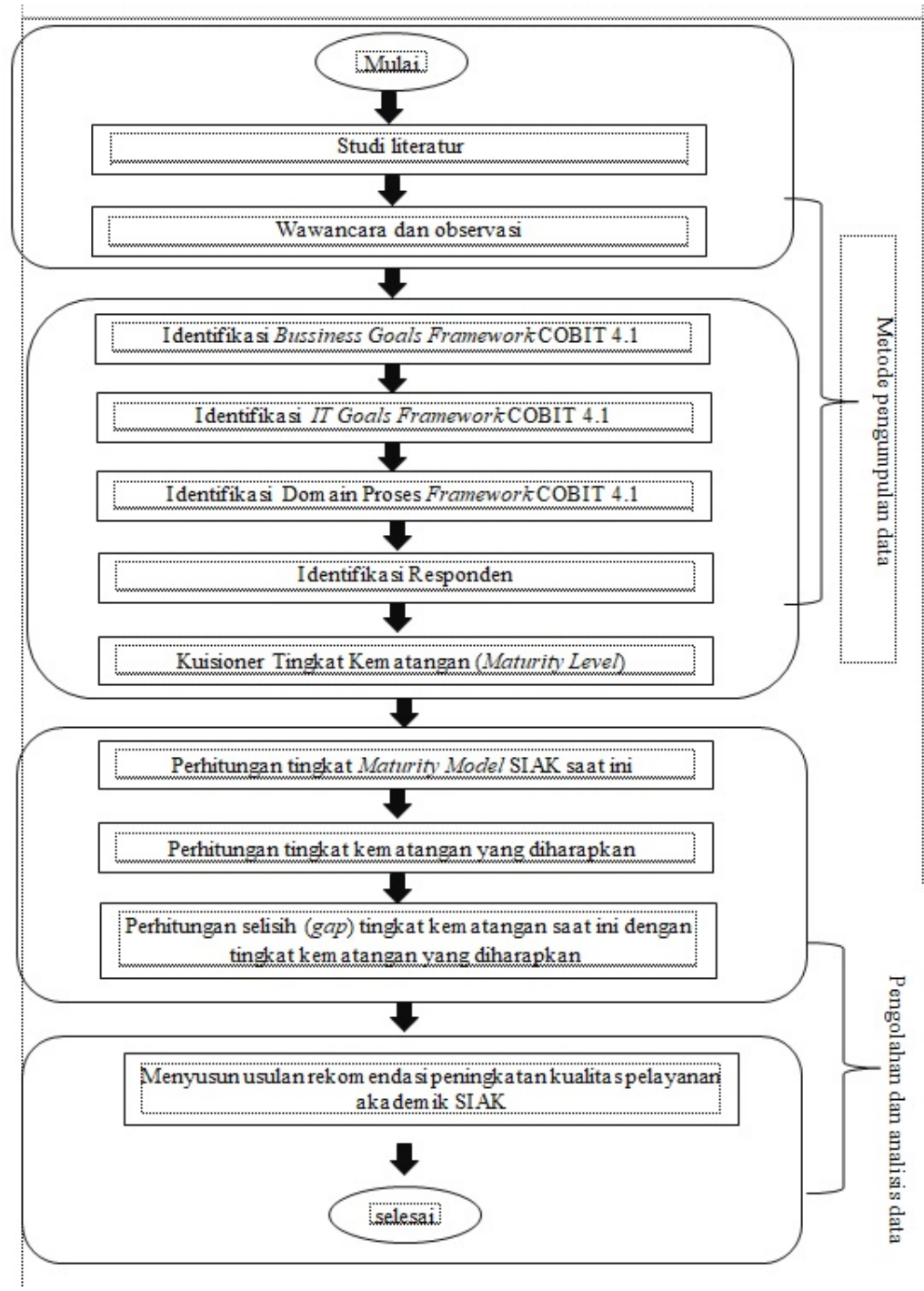

Gambar 2. Alur Penelitian

Berdasarkan gambar 2, alur penelitian dapat dijelaskan bahwa penelitian yang akan dilakukan memerlukan tahapan-tahapan sebagai berikut:

Tahapan pertama yang dilakukan dalam penelitian ini adalah pengumpulan data, dalam tahap pengumpulan data, penulis melakukan studi literatur tentang materi pengukuran tingkat kematangan sistem informasi akademik yang berhubungan dengan penelitian, atau melakukan review terhadap literatur atau jurnal penelitian terdahulu untuk mempelajari metode yang digunakan dalam pengukuran tingkat kematangan sistem informasi akademik. Penulis juga melakukan wawancara dan observasi langsung ke Institut Seni Indonesia Yogyakarta. Kemudian penulis melakukan identifikasi Bussiness Goals, IT Goals, dan domain proses COBIT 4.1 yang akan digunakan dalam penelitian ini. Selanjutnya yang akan dilakukan penulis adalah mengidentifikasi responden yang akan menjawab kuisioner dengan menggunakan $R A C I$ Chart. Tahapan selanjutnya penulis melakukan penyusunan dan penyebaran kuisioner kepada responden yang telah ditentukan untuk dimintai jawaban terhadap pertanyaan yang disusun berdasarkan domain dan standar Framework COBIT 4.1. Responden yang melakukan pengisian kuisioner merupakan pihak-pihak atau sumber data yang dapat dipertanggungjawabkan.

Tahapan kedua adalah tahap pengolahan dan analisis data untuk mengetahui tingkat kematangan sistem informasi akademik yang diterapkan saat ini. Pada tahapan ini penulis melakukan perhitungan data-data dari hasil kuisioner yang telah diisi oleh para responden pada domain-domain yang diteliti untuk menentukan tingkat kematangan sistem pada saat ini. Selanjutnya penulis melakukan wawancara dengan responden untuk memberitahukan tingkat 
kematangan saat ini serta untuk menanyakan tingkat kematangan yang diharapkan. Kemudian penulis melakukan analisis perhitungan mengenai kesenjangan (gap analysis) terhadap kebutuhan untuk menuju ke tingkat kematangan sistem informasi yang diharapkan.

Tahapan ketiga penulis menyusun rancangan solusi sebagai usul rekomendasi yang merupakan tahapan akhir penelitian untuk memberikan sebuah usulan rekomendasi tingkat kematangan sistem informasi akademik.

\section{Hasil dan Pembahasan}

Pada penentuan domain proses yang diteliti pada Institut Seni Indonesia Yogyakarta penulis menggunakan domain proses yang terdapat dalam Customer Perspective dengan Bussiness Goals (Improve Customer orientation and service) serta IT Goals (Make sure that IT services are available as required) sesuai dengan standar yang ada pada Framework COBIT 4.1 .

\subsection{Waktu dan Tempat Penelitian}

Penelitian ini dilakukan mulai dari bulan Juni - Desember 2019 yang bertempat di Institut Seni Indonesia Yogyakarta.

\subsection{Analisis dan Pengolahan Data}

Dalam tahapan ini penulis melakukan analisis dan identifikasi Bussiness Goals yang akan digunakan untuk melakukan penelitian pengukuran tingkat kematangan ketersediaan layanan akademik Sistem Informasi Akademik di Institut Seni Indonesia Yogyakarta . Pada penelitian ini Bussiness Goals yang dipilih oleh penulis adalah Bussiness Goals poin ke 4 yaitu Improve Customer Orientation and Service (Meningkatkan Orientasi dan Layanan Pengguna) yang termasuk dalam Customer Perspective seperti pada tabel 1. dibawah ini.

Tabel 1. Bussiness Goals dalam COBIT 4.1

\begin{tabular}{|l|c|l|}
\hline & & Bussiness Goals \\
\hline \multirow{4}{*}{$\begin{array}{l}\text { Financial } \\
\text { Perspective }\end{array}$} & 1 & $\begin{array}{l}\text { Provide a good return on investment of IT-enabled business } \\
\text { investment }\end{array}$ \\
\cline { 2 - 3 } & 2 & Manage IT-related business risk \\
\cline { 2 - 3 } $\begin{array}{l}\text { Customer } \\
\text { Perspective }\end{array}$ & 3 & Improve corporate governanceand transparency \\
\cline { 2 - 3 } & 5 & Improve customer orientation and service \\
\cline { 2 - 3 } & 6 & Offer competitive products and service \\
\cline { 2 - 3 } & 7 & $\begin{array}{l}\text { Establish service continuity and availability } \\
\text { requirements }\end{array}$ \\
\cline { 2 - 3 } & 8 & Achieve cost optimization of service delivery \\
\cline { 2 - 3 } & 9 & $\begin{array}{l}\text { Obtain reliable and useful information for strategic decision } \\
\text { making }\end{array}$ \\
\cline { 2 - 3 } & & \\
\hline
\end{tabular}

Tabel 1. (lanjutan)

\begin{tabular}{|l|c|l|}
\hline \multirow{3}{*}{$\begin{array}{l}\text { Internal } \\
\text { Perspective }\end{array}$} & 10 & Improve and maintain business process functionality \\
\cline { 2 - 3 } & 11 & Lower process costs \\
\cline { 2 - 3 } & 12 & $\begin{array}{l}\text { Provide compliance with external laws, regulations, and } \\
\text { contracts }\end{array}$ \\
\hline
\end{tabular}




\begin{tabular}{|l|c|l|}
\hline & 13 & Provide compliance with internal policies \\
\cline { 2 - 3 } & 14 & Manage business change \\
\cline { 2 - 3 } & 15 & Improve and maintain operational and staff productivity \\
\hline $\begin{array}{l}\text { Learning and } \\
\text { Growth } \\
\text { Perspective }\end{array}$ & 16 & Manage product and business innovation \\
\cline { 2 - 3 } & 17 & Acquire and maintain skilled and motivated people \\
\hline
\end{tabular}

Kemudian setelah penulis menentukan Bussiness Goals, tahapan selanjutnya adalah menentukan IT Goals. Pada Bussiness Goals poin ke 4 yaitu Improve Customer Orientation and Service terdapat 2 (dua) IT Goals yaitu Ensure satisfaction of end users with service offerings and service levels (Memastikan Kepuasan Pengguna dengan Penawaran Layanan dan Tingkat Layanan) dan Make sure that IT services are available as required (Memastikan Layanan TI Tersedia Sesuai Kebutuhan). Penulis menentukan IT Goals (Make sure that IT services are available as required) untuk digunakan dalam pengukuran tingkat kematangan ketersediaan layanan akademik pada Sistem Informasi Akademik di Institut Seni Indonesia.

Tahapan selanjutnya adalah menentukan Domain Proses, pada IT Goals (Make sure that IT services are available as required) terdapat 4 (empat) domain proses seperti pada Tabel 2. dibawah ini :

Tabel 2. Domain Proses

\begin{tabular}{|c|c|c|}
\hline Bussiness Goals & IT Goals & Processess \\
\hline \multirow{12}{*}{$\begin{array}{l}\text { Improve Customer } \\
\text { Orientation and Service }\end{array}$} & \multirow{8}{*}{$\begin{array}{l}\text { Ensure satisfaction of end } \\
\text { users with service offerings } \\
\text { and service levels }\end{array}$} & PO8 Manage Quality \\
\hline & & AI4 Enable operation and use \\
\hline & & $\begin{array}{l}\text { DS1 Define and manage service } \\
\text { levels }\end{array}$ \\
\hline & & DS2 Manage third-party service \\
\hline & & DS7 Educate and train users \\
\hline & & $\begin{array}{l}\text { DS8 Manage service desk and } \\
\text { incidents }\end{array}$ \\
\hline & & DS10 Manage problems \\
\hline & & DS13 Manage operations \\
\hline & \multirow[t]{4}{*}{$\begin{array}{l}\text { Make sure that IT services } \\
\text { are available as required }\end{array}$} & $\begin{array}{l}\text { DS3 Manage performance and } \\
\text { capacity }\end{array}$ \\
\hline & & DS4 Ensure continuous service \\
\hline & & $\begin{array}{l}\text { DS8 Manage service desk and } \\
\text { incidents }\end{array}$ \\
\hline & & DS13 Manage operations \\
\hline
\end{tabular}

Dari tabel diatas dapat disimpulkan bahwa terdapat 4 (Empat) domain proses yang akan diteliti yaitu DS3, DS4, DS8, DS13.

\subsection{Identifikasi Responden}

Tahapan selanjutnya adalah mengidentifikasi responden berdasarkan RACI (Responsible, Accountable, Consulted, and Informed) Chart pada Framework COBIT 4.1 yang disesuaikan dengan struktur organisasi di Institut Seni Indonesia Yogyakarta seperti yang terlihat pada Tabel 3. dibawah ini :

Tabel 3. Responden

\begin{tabular}{|l|l|c|}
\hline \multicolumn{1}{|c|}{ Raci Responden } & \multicolumn{1}{|c|}{ Actual Responden } & Quantity \\
\hline $\begin{array}{l}\text { Chief Information } \\
\text { Officer }\end{array}$ & $\begin{array}{l}\text { Kepala Bagian Pendidikan dan } \\
\text { Kerjasama }\end{array}$ & 1 \\
\hline Head Operation & Kasubbag Pendidikan dan Evaluasi & 1 \\
\hline
\end{tabular}




\begin{tabular}{|l|l|c|}
\hline \multicolumn{1}{|c|}{ Raci Responden } & \multicolumn{1}{|c|}{ Actual Responden } & Quantity \\
\hline \multirow{3}{*}{ Head Development } & Kasubbag Registrasi dan Statistik & 1 \\
\cline { 2 - 3 } & $\begin{array}{l}\text { Kasubbag Tata Usaha UPT. Pusat } \\
\text { Komputer }\end{array}$ & 1 \\
\cline { 2 - 3 } & Staff UPT. Pusat Komputer & 1 \\
\hline
\end{tabular}

Tugas masing-masing responden dalam mengelola Sistem Informasi Akademik Institut Seni Indonesia Yogyakarta adalah sebagai berikut:

Chief Information Officer (CIO) di bagian Akademik Institut Seni Indonesia Yogyakarta yaitu Kepala Bagian Pendidikan dan Kerjasama, yang membawahi bagian akademik di Institut Seni Indonesia Yogyakarta.

Head Operation ditangani oleh Kasubbag Pendidikan dan Evaluasi serta Kasubbag Registrasi dan Statistik yang bertugas mengelola Sistem Informasi Akademik di Institut Seni Indonesia Yogyakarta.

Head Development ditangani oleh Kasubbag Tata Usaha UPT. Pusat Komputer dan staff UPT. Pusat Komputer yang bertugas untuk memelihara software, hardware yang terdapat dalam Sistem Informasi Akademik di Institut Seni Indonesia Yogyakarta.

Pemilihan responden dilakukan berdasarkan pertimbangan bahwa pihak-pihak tersebut memahami serta memiliki kemampuan dalam melakukan penilaian mengenai ketersediaan layanan akademik pada Sistem Informasi Akademik Institut Seni Indonesia Yogyakarta.

\subsection{Analisis Tingkat Kematangan Data Kuesioner}

Berdasarkan hasil kuesioner, nilai tingkat kematangan ketersediaan Sistem informasi saat ini dan yang diharapkan dapat dilihat pada tabel 4. dibawah ini.

Tabel 4. Hasil Tingkat Kematangan

\begin{tabular}{|l|l|c|c|c|}
\hline Domain & \multicolumn{1}{|c|}{ Proses } & Kondisi Saat Ini & $\begin{array}{c}\text { Kondisi Yang } \\
\text { Diharapkan }\end{array}$ & Gap \\
\hline DS3 & $\begin{array}{l}\text { Manage performance } \\
\text { and capacity }\end{array}$ & 2.76 & 4 & 1.24 \\
\hline DS4 & $\begin{array}{l}\text { Ensure continuous } \\
\text { service }\end{array}$ & 3.35 & 4 & 0.65 \\
\hline
\end{tabular}

Tabel 4. (lanjutan)

\begin{tabular}{|l|l|c|c|c|}
\hline DS8 & $\begin{array}{l}\text { Manage service desk } \\
\text { and incidents }\end{array}$ & 3.25 & 4 & 0.75 \\
\hline DS13 & Manage operations & 2.94 & 4 & 1.06 \\
\hline \multicolumn{2}{|c|}{ Rata-Rata } & 3.07 & 4 & 0.93 \\
\hline
\end{tabular}

Berdasarkan tabel diatas diketahui bahwa nilai kesenjangan pada domain DS3 sebesar 1.24, domain DS4 sebesar 0.65, domain DS8 sebesar 0.75, domain DS13 sebesar 1.06. Nilai gap rata-rata dari semua domain proses yaitu sebesar 0.93. Perhitungan nilai gap didapat dari hasil pengurangan dari nilai tingkat kematangan yang diharapkan dikurangi dengan nilai tingkat kematangan saat ini. Nilai gap nantinya akan digunakan untuk menjadi acuan memberikan masukan terhadap manajemen Institut Seni Indonesia Yogyakarta, sehingga dapat melakukan 
perbaikan untuk meningkatkan ketersediaan layanan akademik dari Sistem Informasi Akademik Institut Seni Indonesia Yogyakarta.

Hasil perhitungan nilai kesenjangan (gap) dari kondisi Sistem Informasi Akademik Institut Seni Indonesia Yogyakarta akan ditunjukkan pada gambar 3. dibawah ini.

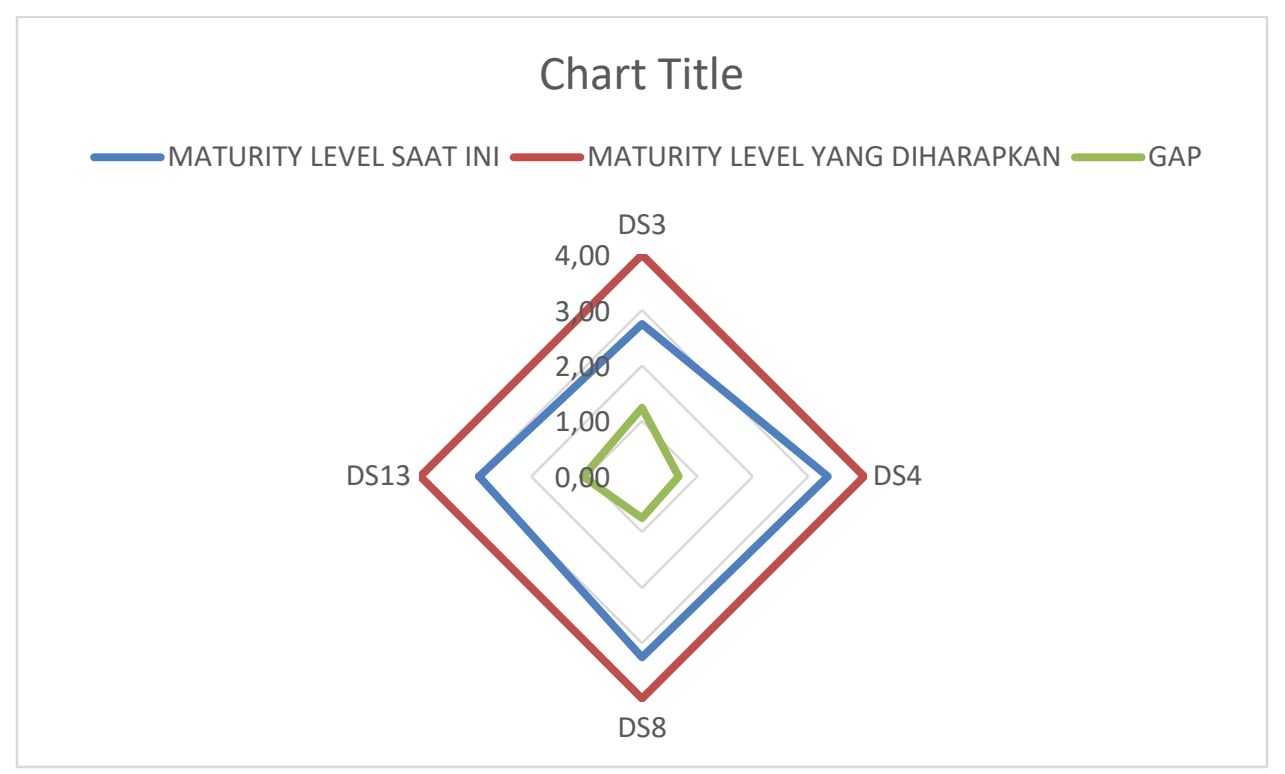

Gambar 3. Grafik Kesenjangan (Gap) Nilai Kematangan Domain Proses

\subsection{Rekomendasi}

Berdasarkan perhitungan diatas dapat diketahui bahwa tingkat kematangan saat ini (asis) pada Sistem Informasi Akademik Institut Seni Indonesia adalah sebesar 3.07. Merujuk pada tabel indeks kematangan, disimpulkan Sistem Informasi Akademik Institut Seni Indonesia Yogyakarta menggunakan framework COBIT 4.1 berada pada tingkat kematangan level 3 (Defined/Sudah didefinisikan) yang berarti prosedur telah standarisasi, didokumentasikan, dan dikomunikasikan melalui pelatihan.

Untuk dapat mencapai tingkat kematangn yang diharapkan yaitu di tingkat kematangan level 4 (Managed and Measurable) peneliti merumuskan rekomendasi sebagai berikut:

a. Rekomendasi proses DS3 - Manage performance and capacity

1. Melakukan evaluasi terhadap kinerja dan kapasitas TI saat ini dengan membandingkan tujuan dan target kinerja yang telah ditetapkan. Menetapkan standar ukuran kinerja dan kapasitas pelaksanaan tingkat layanan TI.

2. Merancang dan mengembangkan tools khusus untuk menentukan standar penentuan kebutuhan kinerja.

3. Merancang dan mengembangkan peralatan terintegrasi yang mampu mendiagnosa kinerja dan masalah kapasitas TI. Menambah kapasitas server serta bandwith untuk meningkatkan performa pelayanan pada SIAK Institut Seni Indonesia Yogyakarta

b. Rekomendasi proses DS4 - Ensure continuous service

1. Walaupun belum ada ancaman, tidak ada salahnya untuk melakukan identifikasi lebih lanjut terhadap resiko, kerentanan, dan ancaman terhadap sistem untuk meminimalisir ancaman yang akan terjadi di masa yang akan dating. 
2. Melakukan pengujian terhadap IT continuity plan dan digunakan untuk mengembangkan plan tersebut. Mengintegrasikan IT continuity plan dengan Bussiness continuity plan serta melakukan pemantauan secara rutin dan berkala

c. Rekomendasi proses DS8 - Manage service desk and incidents

1. Melakukan pendokumentasian terhadap prosedur pengelolaan layanan service desk yang baku dan terstandarisasi dan membuat prosedur untuk pelaporan masalah secara berkala kepada manajemen terhadap hasil penanganan masalah yang sudah ataupun belum terselesaikan. Serta melakukan pelatihan pada staff pengelola Service desk baik secara formal maupun secara informal.

2. Melakukan evaluasi terhadap pertanyaan yang sering diajukan (FAQ) dan panduan pengguna, serta mengembangkan dasar-dasar pertanyaan yang sering diajukan dalam bentuk FAQ dan juga mengembangkan panduan bagi pengguna system.

d. Rekomendasi proses DS13 - Manage operations

1. Institut Seni Indonesia Yogyakarta perlu untuk segera menetapkan, menerapkan, dan memelihara prosedur standar manajemen operasi TI dan memastikan tugastugas yang ada telah sesuai dengan pengguna sistem / staff terkait.

2. Manajemen perlu untuk melakukan monitoring terhadap infrastruktur dan peralatan TI, serta melakukan identifikasi terhadap sumber daya TI yang sudah ketinggalan jaman / spesifikasi nya sudah jauh tertinggal dengan perkembangan teknologi saat ini untuk dapat menetukan sumber daya TI mana yang perlu untuk segera di upgrade agar dapat mengoptimalkan pelayanan di SIAK Institut Seni Indonesia Yogyakarta.

\section{Kesimpulan}

Berdasarkan hasil penelitian yang telah dilakukan maka dapat ditarik kesimpulan sebagai berikut:

1. Nilai kematangan dari domain proses TI terpilih yaitu domain proses DS3, DS4, DS8, dan DS13 pada ketersediaan layanan akademik Sistem Informasi Akademik Institut Seni Indonesia Yogyakarta berdasarkan Maturity Level Framework COBIT 4.1 yaitu sebesar 3.07 atau dengan tingkat kematangan di level 3 (Defined/sudah didefinisikan). hal ini berarti bahwa secara umum ketersediaan layanan Sistem Informasi Akademik Institut Seni Indonesia Yogyakarta pada Proses yang berjalan dilengkapi dengan prosedur yang terstandarisasi, terdokumentasikan, dan dikomunikasikan melalui pelatihan secara formal. Akan tetapi masih ada penyimpangan terhadap ketaatan pada prosedur masih sulit untuk dideteksi. Prosedur yang dibuat merupakan formalisasi dari kegiatan-kegiatan yang ada.

2. Sedangkan tingkat kematangan yang diharapkan (to-be) oleh pihak Institut Seni Indonesia Yogyakarta berada pada tingkat 4 (managed and measurable) yaitu tahap dimana Manajemen mengawasi dan mengukur kepatutan terhadap prosedur dan mengambil tindakan jika proses tidak dapat dikerjakan secara efektif. Proses berada dibawah peningkatan yang konstan dan penyediaan praktek yang baik. Otomatisasi dan perangkat digunakan dalam batasan tertentu. Sehingga diperlukan rekomendasi atau perbaikan untuk mencapai tingkat kematangan yang diharapkan.

\section{Saran}

Berikut beberapa saran yang dapat diberikan kepada pihak Institut Seni Indonesia Yogyakarta adalah sebagai berikut: 
1. Rekomendasi yang telah disusun hendaknya diterapkan di lingkungan Institut Seni Indonesia Yogyakarta untuk mengambil kebijakan didalam meningkatkan ketersediaan layanan akademik pada Sistem Informasi Akademik.

2. Manajemen diharapkan melakukan evaluasi terhadap ketersediaan layanan pada Sistem Informasi Akademik secara terus menerus dan berkesinambungan sebagi pengawasan proses-proses yang ada sehingga dapat menjadi acuan pihak manajemen untuk mengambil keputusan.

3. Diharapkan penelitian selanjutnya dapat melakukan evaluasi dan pengukuran tingkat keberhasilan setelah berjalannya rekomendasi serta melakukan penelitian lebih dalam menggunakan domain proses yang lain pada framework COBIT 4.1.

\section{Daftar Pustaka}

[1] Siswanto, 1997, Memanfaatkan Teknologi Informasi untuk Strategi Keunggulan Bersaing Industri di Perguruan Tinggi Swasta, Makalah Seminar Perguruan Tinggi di Indonesia dalam Transisi Perguruan Tinggi Era Industrialisasi ke Era Informasi, Yogyakarta: Universitas Atma Jaya.

[2] Sarno, R., 2009, Audit Sistem \& Teknologi Informasi, Itspress, Surabaya.

[3]IT Governance Institute, 2007, COBIT 4.1. , http://www.isaca.org/KnowledgeCenter/cobit/Pages/Downloads.aspx

[4]Fenny, Johanes Fernandes Andry, 2017, AUDIT SISTEM INFORMASI MENGGUNAKAN FRAMEWORK COBIT 4.1 PADA PT. ANEKA SOLUSI TEKNOLOGI, Seminar Nasional Sains dan Teknologi 2017 Fakultas Teknik Universitas Muhammadiyah Jakarta , 1-2 November 2017

[5]Lahan Adi Purwanto, R. Teduh Dirgahayu, 2017, Pengukuran Tingkat Kematangan Tata Kelola Pengelolaan Permasalahan Sistem Informasi Akademik Menggunakan Framework COBIT 4.1, JUITA p-ISSN: 2086-9398; e-ISSN: 2579-8901; Volume V, Nomor 2, November 2017

[6] Mayang Anglingsari Putri, Vivin Ayu Lestari, Ismiarta Aknuranda, 2017, Audit of Information Technology Governance Using COBIT 4.1: Case Study in PT. XY, INTERNETWORKING INDONESIA JOURNAL Vol. 9/No. 1, 2017

[7] Supriyaddin, Wing Wahyu Winarno, M. Rudyanto Arief, 2017, EVALUASI TATA KELOLA TEKNOLOGI INFORMASI MENGGUNAKAN METODE COBIT 5 DI STKIP TAMAN SISWA BIMA, Jurnal INFORMA Politeknik Indonusa Surakarta ISSN : 24427942 Vol. 3 Nomor 2 Tahun 2017

[8]Tezhar Rayendra Trastaronny Pastika Nugraha, Wing Wahyu Winaryo, Hanif Al Fatta, 2018, ANALISIS SISTEM INFORMASI AKADEMIK MENGGUNAKAN DOMAIN DELIVERY AND SUPPORT COBIT 5 PADA SMKN 4 YOGYAKARTA, Jurnal Ilmiah d'Computare Volume 8 Edisi Januari, 2018

[9] Wardani, S., Puspitasari, M., 2014, Audit Tata Kelola Teknologi Informasi Menggunakan Framework Cobit Dengan Model Maturity Level (Studi Kasus Fakultas Abc). Jurnal Teknologi , 7, 38-46. 
[10] Wire Bagye, 2016, Analisis Tingkat Kematangan Sistem Informasi Akademik Menggunakan Framework COBIT 4.1 (Studi Kasus: STMIK Lombok), Journal Speed Sentra Penelitian Engineering dan Edukasi - Volume 8 No 1 - 2016

[11] Zakwan S., Ratnawati, S., Hidayah, N.A., 2014, Audit Tata Kelola Sumber Daya Teknologi Informasi Dengan Kerangka Kerja COBIT 4.1 Untuk Evaluasi Manajemen Pada Badan Pengawasan Keuangan dan Pembangunan. Jurnal Sistem Informasi , 1-16.

[12] Andry, J.F., 2016, Audit Sistem Informasi Sumber Daya Manusia Pada Training Center Di Jakarta Menggunakan Framework COBIT 4.1. Jurnal Ilmiah FIFO, VIII, 28-34.a.

[13] Elvis Pawan, Ema Utami, Asro Nasiri, 2018, Mengukur Tingkat Kematangan Tata Kelola Sistem Informasi Akademik Menggunakan COBIT 4.1 dan Balanced Scorecard, Citec Journal, Universitas Amikom Yogyakarta, ISSN : 2460-4259, Vol. 5, Nomor 2, Februari 2018 - April 2018 